\title{
Resurgent Tides Of Nationalism
}

\author{
Tengku Ahmad Hazri *
}

In recent months, the rise of nationalism has been associated with the return of xenophobia, anti-immigration sentiments, populism and far-right, neo-fascist conservatism. In consequence, nationalism has been much maligned and made the scapegoat for Brexit, the rise of Donald Trump, 'Putinism' and China's intransigence on issues like Taiwan. Putin's expansion towards the East, for example, has been construed in certain media circles as a revival of Eurasianism, a policy advocated by Russian thinkers from Prince Nikolay Trubetskoy and Lev Gumilev to Alexander Dugin. Certainly, Putin's 2012 allusion to Gumilev's passionarnost (the Russian equivalent of Ibn Khaldun's 'asabiyya) was taken to hint at a revival of Eurasianism.

There have been two factors running parallel to these developments: a cynicism towards democracy and greater calls for the restraint of popular sentiments through the rule of law. Democracy, long promoted as a means of mass empowerment, is now pejoratively viewed as the backdoor to populism. Stark examples include how referendums - democracy pushed to its furthest frontiers - have produced Brexit in the UK and separatism in the Crimea (blamed on the aforementioned Eurasianism). Democracy, it is now alleged, gives rise to the tyranny of the majority_or, in more fashionable parlance, to 'illiberal democracy'.

This present and pervasive vilification of nationalism sits rather uneasily within post-colonial societies whose nation-building projects are very much a work-in-progress. Faced with the challenge of managing diverse communities and groups, for decades these societies have used nationalism as a rallying point for transcending these differences; the nation is supposed to be different from, and to transcend, all ethnic, religious and cultural boundaries. It is the space in which all communities can converge and share values.

Nationalism, even when unspoken, has therefore functioned as a default ideological template for many nation-states, being perceived as the common basis upon which diverse identities can converge. Nationalism outside Europe has emerged as an antidote to sectarianism and parochialism in societies that have been divided by race, ethnicity and religion. It has also offered a common voice against colonising powers. For this reason, a distinction has commonly been made between ethnic nationalism and civic nationalism. Whereas ethnic nationalism is based on a single ethnic group, civic nationalism relies on the construction of a common civic identity. 
In the Muslim world, nationalism played a key role in the short-lived merger of Egypt and Syria to form the United Arab Republic (UAR) in the late 1950s. It was also under the nationalist spirit that Arab states, during the so-called 1970s oil crisis, were able to respond to the US's assistance towards Israel by launching an oil embargo that devastated the US economy, compelling the US to realign its policies towards the Gulf States, particularly Saudi Arabia.

In pre-Independence Malaya, the left-leaning intellectual-politician Burhanuddin al-Helmy's nationalist thought censured the French intellectual Ernest Renan's narrow conception of 'nation' and instead embraced Otto Bauer's wider conception of nation as "a community of conduct arising from a community of destiny." Burhanuddin thereby dissociated Malay nationalism from Malay ethnicity, making the case for the inclusion of diverse ethnic and hereditary communities in the Malay 'nation', formulating his thought in the vein of Mahatma Gandhi (via Sukarno), "I am a nationalist, but my nationalism is humanity".

By contrast, China takes a distinctive attitude towards race and ethnicity, and in a manner which eminent China scholar Martin Jacques has described as "nonnegotiable." This is the belief that the Han Chinese are superior, conceived of as a single race with even distinct biological origins from the rest of humanity. The non-Han Chinese are even seen as different nationalities altogether.

In Turkey, the Kemalist legacy created a new civic community based on Turkish identity. This backfired, however, when the constitution's identification of all citizens as Turks provoked discontent among its minorities, particularly the Kurds. As this debate continues to unfold today, Turkey's proposed new constitution seeks to address this very problem, which the AKP had earlier initiated with its "Kurdish opening" (Kürt açılımı).

Perhaps the bitterest story, however, revolves around the rise of Buddhist nationalism in South East Asia, particularly Myanmar. This has led to antipathy towards and widespread persecution of the Rohingyas, Myanmar's Muslim minority. The Myanmar scenario is illustrative of the dangers of state monopoly over the identification of ethnicity; under Myanmar law, only 'recognised' ethnic groups can qualify as citizens. Because the Rohingyas are not recognised as such, they are seen as "Bengalis" and subject to numerous discriminations.

\section{Notes}

* Tengku Ahmad Hazri is Research Fellow at IAIS Malaysia. He may be reached at ahmhazri@iais.org.my. 